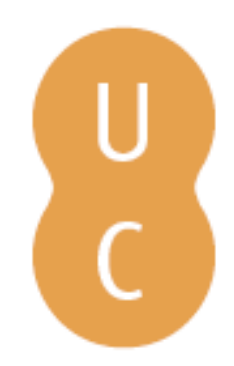

\title{
pompalina
}

\section{Examination of the forest fires detection: the relationship between the fire and the detection}
Autor(es):
Bodnár, László; Restás, Ágoston
Publicado por: Imprensa da Universidade de Coimbra
URL
persistente:
URI:http://hdl.handle.net/10316.2/44626
DOI:
DOI:https://doi.org/10.14195/978-989-26-16-506_109
Accessed : $\quad$ 26-Apr-2023 11:32:05

A navegação consulta e descarregamento dos títulos inseridos nas Bibliotecas Digitais UC Digitalis, UC Pombalina e UC Impactum, pressupõem a aceitação plena e sem reservas dos Termos e Condições de Uso destas Bibliotecas Digitais, disponíveis em https://digitalis.uc.pt/pt-pt/termos.

Conforme exposto nos referidos Termos e Condições de Uso, o descarregamento de títulos de acesso restrito requer uma licença válida de autorização devendo o utilizador aceder ao(s) documento(s) a partir de um endereço de IP da instituição detentora da supramencionada licença.

Ao utilizador é apenas permitido o descarregamento para uso pessoal, pelo que o emprego do(s) título(s) descarregado(s) para outro fim, designadamente comercial, carece de autorização do respetivo autor ou editor da obra.

Na medida em que todas as obras da UC Digitalis se encontram protegidas pelo Código do Direito de Autor e Direitos Conexos e demais legislação aplicável, toda a cópia, parcial ou total, deste documento, nos casos em que é legalmente admitida, deverá conter ou fazer-se acompanhar por este aviso.

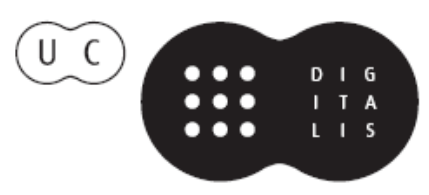




\section{ADVANCES IN}

\section{FOREST FIRE RESEARCH}

\section{8}

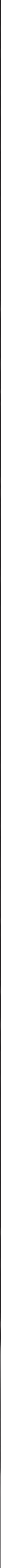




\title{
Examination of the forest fires detection - The relationship between the fire and the detection
}

\author{
László Bodnár *; Ágoston Restás \\ 1* National University of Public Service, Hungary. 1101, Budapest, Hungária krt. 9-11, \\ \{bodnar.laszlo@uni-nke.hu*,restas.agoston@uni-nke.hu\}
}

\begin{abstract}
Introduction: Forest fires are one of the most typical natural disasters in the world. As a result of the global climate change a continuous average temperature increase can be determined. Consequently, the risks of the forest and the vegetation fires are increasing. Because of the global climate change, the dry and rainless periods of the weather conditions can be extended. It gives bigger opportunity to ignite the biomass. For the effective firefighting it is necessary to make a quick detection. The detection of the forest and vegetation fires is carrying out mostly on a passive way, mainly based on public announcement. If there is no announcement of a fire, it does not mean a fire for the fire departments. So that is why the authors make an examination of the forest fire detection, focusing on the relationship between the fire and the detection.

Methods: When writing the paper, it was important to analyze and study the relevant literatures of the topic, and the related data collection. In addition, it is important to mention the personal consultations with various experts, the logical conclusions and the personal experiences of the authors on the subject. The authors expressed the effectiveness of the observation with an simple mathematical formula.

Results: The authors set out to examine the detection of the forest and vegetation fires as a factor influencing on the effective firefighting. The paper shows the relationship between the observer and the fire. The authors were analyzing the operation methods of the human eyes. Including the importance of the angle of view, the whole field of view of the human eyes. In the paper appear the obstructive factors of the detection, such as the distance and the terrain. As a result of the paper, the authors determined a formula, which shows the efficiency of the observation and its most important circumstances.
\end{abstract}

Keywords: forest fire, vegetation fire, observer, detection, efficiency, angle of view

\section{Introduction}

The global climate change is a real threat in the past decades, (Westerling ALR. 2016) but it has begun in the 20th century. (Morgan et al. 2008) Global warming affects all elements of firefighting. The in time observation of the forest fires is very important, as it has an indirect impact on the size of burned areas and on the effectiveness of firefighting. Firefighting is a very long and complicated process that requires proper firefighting tactics and well - considered decisions from the leader of the firefighting. (Restás 2015) When doing researches in connection with the detection of the forest fires, it is very important to mention some results from other authors. According to Ahmad A. A. Alkhatib 2014 there are a lot of methods and systems, which can help for the early detection. Each technique has its own advantages and disadvantages. For example, a well-functioning camera system can be a big help in the early detection. Authors like other experts prefer unnamed aerial vehicles for the effective detection. Drones can monitor forest fires and make measurements (L. Merino et al. 2012) or software's can provide functions on processing UAV aerial image data, according to the requirements of forestry area application on UAV platform. It gives a real-time and remote watch on fires. (Lan Zhang et al. 2015) But there are some other researchers, who suggest wireless sensor networks for the reliable detection. It promises green technology for the future in detecting efficiently the forest and the vegetation fires. (Bouabdellah et al. 2013) In case of a fire, in many cases the innovative devices are not available. Fire detection is a civic duty in which the efficiency of the fire detection depends on the observer. Authors will examine this problem and its circumstances. 
A firefighting process is a result of many complex steps. However, these steps can be called effective only when the first steps are time-consuming. These first steps will take place even before the marching of the professional fire departments. The most important of these steps are the generation of the fire, the fire detection, and the assessments of fire detection, the determination of alert state and the alarm. This is illustrated in Figure 1 below.

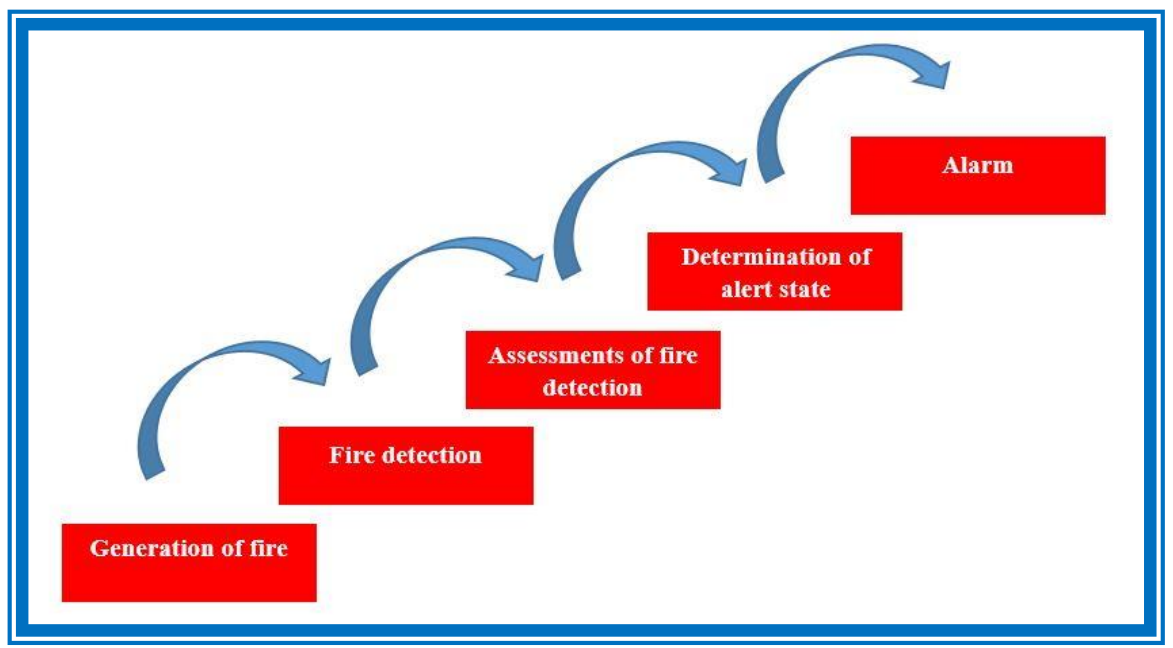

Figure 1 - The first 5 steps in the firefighting process

It is a fact that most of forest fires are the result of human negligence or intent, therefore, the authors state that the first two steps of the firefighting process are related to the citizens. The generation of fires can be prevented by laws and modern innovative tools. (Blum 2012; Condera et al. 2012) However, in many cases they do not provide the opportunity to prevent the fires. The generation of a fire causes heat and fumes. The colour of smoke can be detected within a short time by the citizens. The quickness of the observation and the signalling is very important, as the later the fire alarm is realized, the later the professional fire departments will be alerted, and it will result in more burnt areas. It means significant costs for the national economy. (Restás 2014; Bodnár 2017)

In connection with the firefighting it is important to mention that according to common law, who detects a fire has an obligation to signal it to the professional fire departments. If it is not possible, the observer has to make a signal for the police, the ambulance service or the mayor's office of the competent municipality.

The fire detection can be done by personal communication, by telephone or by voice and light signalling systems. In this case the most important facts are the quickness and the statement. According to the experiences of experts the observer must always report:

- The exact location of the fire

- What is burning?

- What kind of damage has happened

- What is in danger (gas tanks, dangerous goods, vehicles)

- Is there a life threat?

- The name and phone number of the observer

The statement and the speed of these data are very important for the effective firefighting. However, detection of fire is not always easy. There are some cases when detection is affected by various circumstances. In addition, it is important to examine and analyse the angle of view and the function of the human eye. With this function, the authors make considerations in the following chapter. 


\section{Examining the function of the human eye and the angle of view}

A basic condition for remote detection is that it has to reach the minimum level of the sensitivity threshold of the detection. The typical parameter of the fire is the smoke, which can be detected visually even from a long distance. The smoke is a complex flue-gas system. Its composition depends on the combustible material and the conditions of combustion. The most important factor in the burning of vegetation is the water content of the vegetation. Depending on the circumstances, the location of the burning vegetation can be observed from long distance, because of fume. The observation is basically influenced by the colour and intensity of the smoke, the water content of the given vegetation and the atmospheric conditions. The released aqua vapour during the combustion dyes the fumes grey-white. The opportunity of the long distance detection is determined by the distance between the observer and the fire, the obstacles between them and their relative positions. But it is also important to investigate field of view and the operation of the photoreceptors.

Eye is one of the most important senses of people. By using our eyes, we are able to detect and find out everything. The field of view is the space that our eye sees in straight forward look. During a perimetry, the two eyes must be examined individually. Looking straight forward, the eye fixes a point, in the visual field hemispheres, but whenever a spotlight is displayed, it is indicated by a button push. During the perimetry, the testing hemisphere and the intensity of the test light are accurately calibrated. Based on the test signal, two types of perimetry can be distinguished.

During the kinetic perimetry, the light point is moved by the investigator in the perimeter sphere from the periphery to the centre (hence kinetic). The circle or oval line within which the test point of a given size and brightness is detected by the test is a so-called isopter. The ability of the light sensor retina is centrally the largest, and to the edge is gradually more imperceptable. Therefore, the smaller and weaker is the test point, the smaller is the associated isopter, so the field of view is narrower.

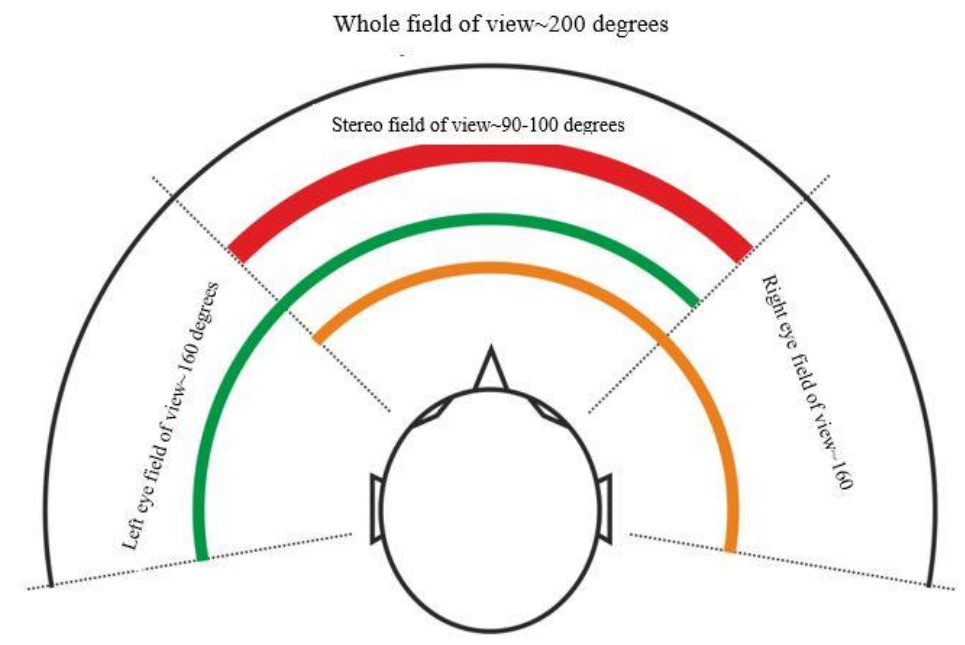

Figure 2 - The whole field of view of the human eyes. Source (Süveges 2010)

During the static perimetry, the test signal does not move, but it is displayed at different locations with different light intensity. The purpose of the test is to determine the light detection threshold value at the retinal sites under examination. (Steven 2016)

According to the Figure 2, the human eye is generally capable of measuring a 200-degree angle. Within the field of sharp eyesight, in the centre of the field of vision, the eyes are able to see angle of view about 90-100 degrees. Within this area, a healthy person's eyes can detect anything and capture it in brain in a good quality. (red line) If the two eyes are examined separately, it can be stated that the angle of view of each eyes has approximately an angle of 160 degrees. (green and orange lines) 
Separately, they do not cover the entire field of view but the full visibility is achieved only with the operation of both eyes.

The importance of the eyes and the field of view also plays a significant role in the detection of fire. Detection is effective if the observers perform their activity at the widest possible angle and in the best possible quality. If these two conditions are not fulfilled, the detector may receive a false image of the fire and the fire spread. As a result of this, false data can be sent to the professional fire departments, which also has an influence on the number of the alert forces and on determination of the alert state. Almost everywhere, a large number of forest fires were generated due to bad detections data due to classifications of the alert state. Later this problem was solved by the leader of the firefighting. (Bodnár 2017)

As a result of this chapter, the authors stated that the detection may have a significant effect on firefighting. Because the detection of a fire is still made by the citizens in most cases, it is very important to examine the function and the operation of the human eye. If a person who detects a fire does not perform their obligation well, it will result in a more complicated intervention for the firefighters. The incorrect detection gives a bad signal to the interveners, so it will lead to problems during the firefighting. In addition, it means extra costs for the national economy

\section{Factors hindering the detection}

The early detection of the generation of fire is very important. In some cases, observation is hampered by various obstacles. In this chapter, the authors examine the obstacles of the fire detection and its methodological background. If the fire is detected from a long distance it is important to have a feature which reaches the minimum level of sensitivity threshold for the detection. The characteristic parameter of the fire is smoke. It can be perceived visually from even longer distance.

\subsection{Examining the role of the distance in connection with the detection}

One of the most typical difficulties of detecting a fire is distance, because this is a factor that basically has a major influence on the effectiveness of the observation. In this connection, the authors still consider that it is important to examine the function of the human eyes and its adaptation to the distance. The eyes must also give a sharp picture from various distances in order to keep the image distance. it is facilitated by the long-distance adaptation and accommodation of the eye.

The eyepieces are fixed to the ciliary body in the surroundings with a help of so-called elastic and inflexible lenses. If the ciliary muscle relaxes in the ciliary body (resting position), then the hanging fibres are strained, so the eyepiece will flatter and the focal length will be greater. It is called far-reaching adaptation. If the ciliary muscle will contract, (the diameter of the radial body decreases) the hanging fibres will slack, so the flexible lens will curle, and its focal length will decrease. This is the close adapted eye. Without any exertion the normal eye can adapt to the distance of so-called perspicacity. For a healthy eye, the clearity distance is approximately $25 \mathrm{~cm}$. (Goldsmith 1990) Of course, detecting forest fires, the observer cannot detect from a $25 \mathrm{~cm}$ of distance. Its distance is significantly higher. (Dancy and Christian 2014) Of course, the eye can adapt to longer distances. Its operation is illustrated in Figure 3. While increasing the distance, the possibility of the observation decreases proportionately. The reason for this is that on one

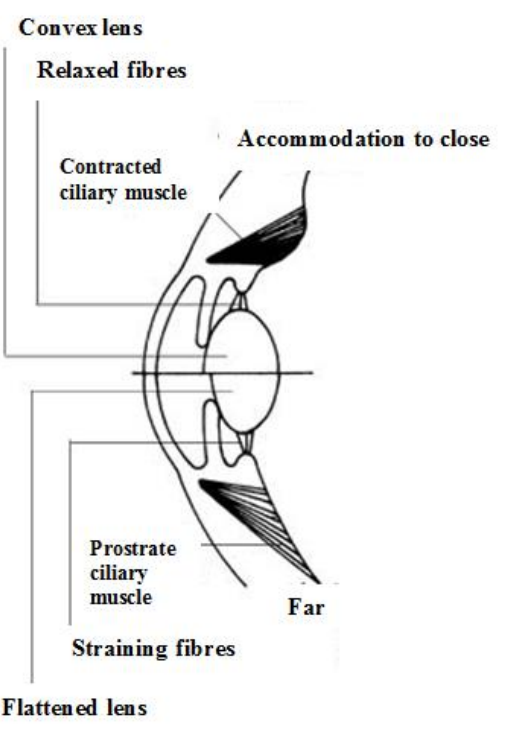

Figure3 - The long distance adaptation of the human eye. Source: (Sulinet 2018) 
hand the visible surface decreases in proportion to the square of the distance and, on the other hand, the humidity of the air reduces the visibility of the contours. If the smoke does not reach the threshold of sensitivity of the observer, it remains invisible.

When examining the operation of the eye it can be stated that our eyes can adapt to various distances. However, in some cases, because of the distance between the eye and the detected area, the observer can get distorted view. It can also have an affect to the fire alarm. But when the observer does not get a real picture of the circumstances of the fire, the signal can be false. In the case of a false fire alarm, the marching will be unnecessary. It means further costs for the economy system.

\subsection{Other obstacles during a detection}

After investigating the detection and the distance, the authors consider to analyse other obstacle factors during the observation.

There may be many obstacles between the location of the observer and the burning area. It can reduce or exclude the possibility of detection. It could be for example the terrain and the vegetation of the detected area. The perceptibility of various fires in valleys can only be observed by the smoke, when it rises above the top of the vegetation. In this case, the flames can not be detected. In many cases, it has led to major problems, because basically, smoke does not always mean a fire in the forest. Ignition is allowed at designated fireplaces in the forest, but it has also smoke phenomenon. In many cases the observer thinks of this and not of a real forest fire. In addition, it is considered by the authors to mention that the content of the air humidity and the relative humidity reduces the option of the detection in proportion with the distance. In addition, it should be noted that the low humidity increases to both the propagation of fire and the possibility of the detection.

The detection of forest fire is basically influenced by the relationship between the observer and the fire. It can be an advantage or even a disadvantage in the detecting activity. The lower level you can imagine it in a hilly, pointed area when the observer is in the valley and the fire on a hillside or on a hilltop. In this case, the angle of view allows not only the detection of the smoke, but also the visibility of the frontline of the fire. This is a clear sign of a forest fire, so the phenomenon of smoke does not deceive the observer, so he can warn quickly. The same level of the location allows the detection of smoke, the visibility of the frontline of the fire depends on the height of the vegetation or the parameters of the fire. In this case, there can be some doubts from the observer, because he cannot see the flames, only the smoke. The higher detection level of the observer allows the detection of both the smoke and the frontline of the fire due to the better angle of view. The smoke can reduce the detection of the frontline fire. Detection has a psychological background as well. It has been a concern for a long time. (Wade and Rovira 1981)

Table 1 - The observer's relationship to the fire.

\begin{tabular}{|c|c|c|c|}
\hline $\begin{array}{c}\text { observer's } \\
\text { relationship with } \\
\text { the fire }\end{array}$ & $\begin{array}{c}\text { only smoke } \\
\text { detection }\end{array}$ & $\begin{array}{c}\text { flame and } \\
\text { smoke } \\
\text { detection }\end{array}$ & $\begin{array}{c}\text { only flame } \\
\text { detection }\end{array}$ \\
\hline lower & & $\mathrm{X}$ & \\
\hline same & $\mathrm{X}$ & & \\
\hline higher & & $\mathrm{X}$ & \\
\hline
\end{tabular}

As a result of this chapter, the authors define a formula for the effective human detection. The efficiency of the detection is influenced by the distance between the fire and the observer, the time of the detection (response time), the terrain of the area and the phenomenon of the flames and smoke. In this context, these factors will be reflected in the formula defined by the authors.

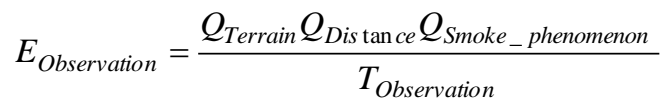

- EObservation: effectiveness of the observation 


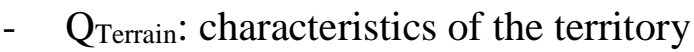

- QDistance: distance between the fire and the observer

- QSmoke_phenomenon: characteristics of the smoke (fire)

- Tobservation: time between fire ignition and observation

$$
\begin{aligned}
& O=\frac{\mathrm{S}+\mathrm{Te}+\mathrm{Ph}}{\mathrm{To}} \\
& \text { O: Observation } \\
& \text { Te: Terrain } \\
& \mathrm{S}: \text { Distance between the fire and the observer } \\
& \text { To: Time of the Observation } \\
& \mathrm{Ph} \text { : Phenomenon } \\
& \text { Figure } 4 \text { - Formula of the efficient observation. }
\end{aligned}
$$

According to the formula the authors determined the efficient detection. The efficient observation is realised, when the observer in a certain period of time (To), from a certain distance (S), under certain terrain conditions $(\mathrm{Te})$ detects a phenomenon of fire $(\mathrm{Ph})$ and warns the disaster management. The less time it is realized the fire alarm will be more efficient. A quick fire detection is a key for the effective firefighting. In connection with the early detection it is important to mention that beside the human observation, there are other technical solutions (for example drones) to detect the wildfires. Many suggestions have been made to this in the international publications in connection with forest fires (Restás 2015; Bodnár et al. 2018) and in other fields of science (Muyambo et al. 2017)

\section{Summary}

In this article, the authors set out to examine the detection of the forest and vegetation fires. The paper also examines and analyse the operation and methodology of the human eye, as well as the conclusions and actualities to the wildfires. In addition, the authors performed a research in connection with the detection factors and the difficulties of the observation. In this context, the potential connections of the observer were presented to the fire, thus examining the circumstances of the detection.

The result of the paper is a formula defined by the authors that determines the effectiveness of the fire detection. It is important because the first step in any firefighting activity is the fire detection of the citizens. If it does not happen quickly and efficiently, it significantly determines the effectiveness of firefighting. The number of the intervening forces depends on the fire detection and on the previous experiences. If less fire forces will be alerted, the leader of the firefighting has to alarm more fire forces. It takes time. During this period of time, the size of burned areas will grow continuously, which means significant expense to the national economy system.

In addition, the authors drew attention to the importance of false fire detection. Even in this case, they are alerted by professional fire brigades and they are on the scene due to the signal. Different alarms of a fire have their own costs, even if it is a false alarm; it means more costs for the economy system. Overall, it can be stated that early detection of fire is extremely important, so it requires further researches and analysis.

\section{References}

Ahmad A. A. Alkhatib (2014) A Review on Forest Fire Detection Techniques. International Journal of Distributed Sensor Networks 10, 1-12.

\section{http://journals.sagepub.com/doi/pdf/10.1155/2014/597368}


Blum, S. (2012) Eine neue Methode warnt vor Waldbrand. Tierwelt 31, 22-23.

Bodnár L (2017) Case study of "Hortobagy" and "Kunfeherto" fires, Hungary: disaster in costs of their elimination's view. Ecoterra: Journal of environmental research and protection 14, 40-46.

Bodnár L, Restás Á, Qiang X (2018) Conceptual Approach of Measuring the Professional and Economic Effectiveness of Drone Applications Supporting Forest fire Management. Procedia Engineering 211, 8-17.

Bouabdellah K, Noureddine H, Larbi S, (2013): Using Wireless Sensor Networks for Reliable Forest Fires Detection. Procedia Computer Science 19, 794-801.

Condera, $\mathrm{M}$ et al. (2012): Verifica sperimentale del sistema FireLess2: stima dell'umidità dei combustibili forestali e del pericolo di incen- dio. Sherwood 18, 185, 25-31.

Dancy M, Christian W (2014) The applet of my eyes. (Translate: Nagy S) https://nagysandor.eu/ChristianBelloni/optics/applications/illustration36_1.html (download 22 ${ }^{\text {th }}$ of June 2018)

Goldsmith T. H (1990) Optimization, Constraint, and History in the Evolution of Eyes. The Quarterly Review of Biology 65, 281-322

Lan Z, Bing W, Weilong P, Chao L, Zeping L, Yan G (2015): A Method for Forest Fire Detection Using UAV. Advanced Science and Technology Letter 81 69-74. https://pdfs.semanticscholar.org/c353/eec25fc3a25675e57e129817a94ac7e1c136.pdf

Merino L, Caballero F, Martínez-de-Dios J. R, Maza I, Ollero A, (2012) An unmanned aircraft system for automatic forest fire monitoring and measurement. Journal of Intelligent \& Robotic Systems $\mathbf{6 5}$ 533-548

Muyambo F, Restás A, Jordaan A, Bodnar L, (2017) A life-saving technology supporting crisis management unnamed aerial vehicle (UAV) application in developing countries. Delta XI, 20-27.

Morgan P, Heyerdahl EK, Gibson CE. 2008 Multi-season climate synchronized forest fires throughout the 20th century, northern Rockies, USA. Ecology, 89 717-728.

Restás Á (2014) Theoretical approaches for evaluating the economic efficiency of the aerial firefighting helping strategic planning In: Domingos Xavier Viegas Luis Mário Riberio, Abstracts of the VII International Conference on Forest Fire Research.Coimbra, Portugal, 2014.11.142014.11.21. Coimbra: University of Coimbra, 2014. p. 17. 1 p.

Restás Á (2015) Drone Applications for Supporting Disaster Management. World Journal of Engineering and technology 3, 316-321

Restás Á (2015) How fire managers make decision in case of time pressure. In: W J de Groot The 6th International Wildland Fire Conference. Seoul, South Korea, 12.10.2015-16.10.2015. Seoul: Institute for Environmental Technology and Sustainable Development, Korea University, 2015. Paper 0508.

Steven M. LaValle (2016) Virtual Reality. Cambridge University Press. Cambridge http://msl.cs.uiuc.edu/vr/vrch5.pdf

Sulinet (2018) http://tudasbazis.sulinet.hu/hu/termeszettudomanyok/fizika/fizika-11-evfolyam/azemberi-szem/a-szem-alkalmazkodasa-a-tavolsaghoz (download $20^{\text {th }}$ of June 2018)

Süveges I (2010) Szemészet. (Medicina Publishing: Budapest)

Wade M, Rovira M (1981) Signal Detection Theory - Its Implications for Social Psychology. Personality and Social Psychology Bulletin 7, 232-239.

Westerling ALR (2016) Increasing western US forest wildfire activity: sensitivity to changes in the timing of spring. Philosophical Transactions Biological Sciences 371, 1-10. 